\title{
An audit of characteristics and outcomes in adult intensive care patients following tracheostomy
}

\author{
Yiu Ming Ho, A. Peter Wysocki, James Hogan ${ }^{1}$, Hayden White ${ }^{2}$
}

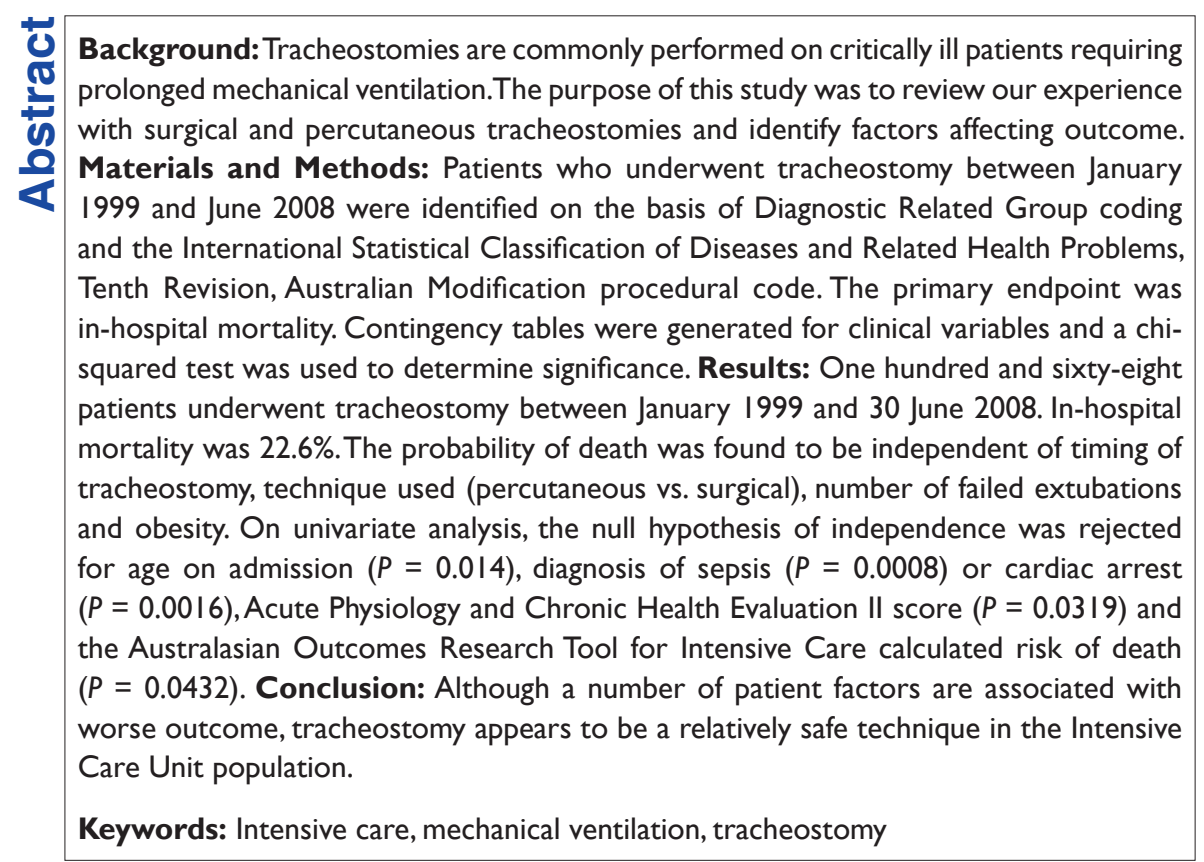

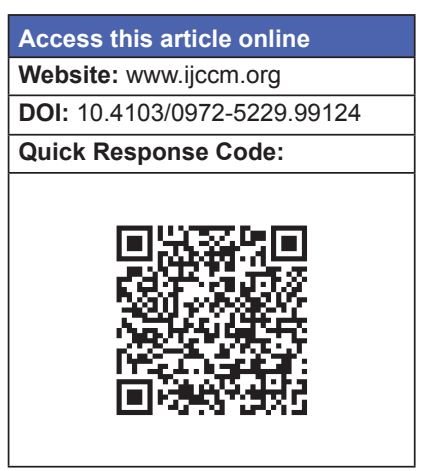

\section{Introduction}

Tracheostomy is a commonly performed procedure to facilitate prolonged ventilator-based respiratory support in patients with respiratory failure, and may be carried out in up to $10 \%$ of all Intensive Care Unit (ICU) admissions. ${ }^{[1]}$ Tracheostomy provides several potential advantages over prolonged endotracheal intubation, including improved respiratory mechanics with less dead space ventilation, decreased length of ICU or hospital stay and improved pulmonary toilet and comfort. ${ }^{[2-8]}$ Recent studies have also demonstrated that tracheostomy results in fewer oral-labial

\section{From:}

Departments of General Surgery and ${ }^{1}$ Intensive Care, Logan Hospital, Queensland, Australia, ${ }^{2}$ Wiltshire Hogan Ltd., Wellington, New Zealand

\section{Correspondence:}

Dr. Hayden White, Logan Hospital, Corner Armstrong and Loganlea Roads, Meadowbrook, Queensland 4131, Australia.

E-mail: hayden_white@ @ealth.qld.gov.au ulcerations, lower incidence of pulmonary infections and lower sedative requirements. ${ }^{[7,8]}$ Furthermore, newer techniques such as percutaneous dilatation tracheostomy (PDT) have been shown to be cost-effective and safe, offering clinicians an effective alternative to surgical tracheostomy (ST).

Despite the continuous advancement in techniques including the use of bronchoscopy and ultrasound guidance, complications following tracheostomy are not uncommon. ${ }^{[3]}$ These include infection, bleeding, obstruction from posterior membranous trachea and infraglottic stenosis $(1.6-10 \%$, including asymptomatic, bronchoscopic or computed tomography [CT]-proven stenosis). ${ }^{[9-12]}$ Tracheoarterial fistula is a rare $(<1 \%)$ complication, but can lead to massive hemoptysis and death. ${ }^{[13]}$ Bronchoscopy, as an adjunct for tracheostomy, is also not without drawbacks, including compromised ventilation causing hypoventilation, carbon dioxide 
retention, increased cost and time. ${ }^{[14,15]}$ It is therefore necessary to ensure that the procedure is only performed in the appropriate setting.

Unfortunately, controversy continues to exist regarding a number factors related to tracheostomy in the ICU population, including indications, timing and procedure (PDT vs. ST). ${ }^{[16-21]}$ The issue is further complicated by the difficulty in predicting the need for prolonged ventilation, which is an indication for tracheostomy. ${ }^{[22]}$ Therefore, the purpose of this study is to review the role of tracheostomy in a regional medical/surgical ICU with a view to understanding factors affecting patient selection and outcome.

\section{Materials and Methods}

Data was extracted through Transition II database (Queensland Health Administrative database). The study period was from 1 January 1999 to 30 June 2008. Sample selection was based on tracheostomy Diagnostic Related Group (DRG code A06Z) and the procedural code for tracheostomy in International Statistical Classification of Diseases and Related Health Problems, Tenth Revision, Australian Modification (ICD-10-AM code 41883-00). Data was stored as a Microsoft Excel ${ }^{\circledR}$ file. Data in the sample were manually verified by chart review. Acute Physiology and Chronic Health Evaluation II score (APACHE II) was obtained from the Australasian Outcomes Research Tool for Intensive Care (AORTIC) database kept by the ICU (calculated on admission to ICU). The calculated risk of death scores was also retrieved from the AORTIC database (represents a multivariate additive linear regression model). Statistical analysis was performed using SAS Version 9.13.

The following data were obtained from the administrative database: admission and discharge date and discharge status. The following were obtained from each patient's medical chart: admission source, primary and secondary diagnoses, number of failed extubations, timing of tracheostomy, type of tracheostomy (surgical or percutaneous), obesity (body mass index $>30 \mathrm{~kg} / \mathrm{m}^{2}$ or weight $>92 \mathrm{~kg}$ ). Presence of infection was determined from the primary and secondary diagnoses. Sepsis was considered to be present if the term was recorded in a clinical entry in the medical record prior to tracheostomy date.

Ethics approval for this study was obtained from the Human Research Ethics Committee (EC00167); reference 2008/049.

\section{Results}

The Logan Hospital is a general peri-urban hospital with 350 acute medical beds. The ICU is a mixed medical/surgical unit, although approximately $80 \%$ of the cases are medical. The number of ventilated cases has increased from 35 in 1999 to 279 in 2008 [Table 1].

One hundred and eighty-one records were identified from the Transition II database. Thirteen patients were excluded (seven did not have a tracheostomy performed; one had tracheostomy performed in another hospital; two charts were missing; one chart was incomplete; one underwent change of tracheostomy tube only; one patient entry was duplicated). Forty-one data errors in the revised sample were corrected during verification (e.g., ICU admission date, tracheostomy date, etc.). Thirty-eight patients died in-hospital of the final sample size of 168 patients $(22.6 \%)$.

Overall, 90 patients were male and 78 female. Twentyfour male $(27 \%)$ and 14 female patients died $(18 \%)$, but this difference was not statistically significant $(P=0.2)$. Age on admission ranged from 22 to 87 years (mean

\begin{tabular}{|c|c|c|c|c|c|c|c|c|c|}
\hline Primary diagnosis & Number & Deaths & $\begin{array}{c}\text { Mortality } \\
\text { (\%) }\end{array}$ & Nr male & $\begin{array}{l}\text { Mean age } \\
\text { (years) }\end{array}$ & $\begin{array}{c}\text { Mean ICU } \\
\text { day } \\
\text { tracheostomy }\end{array}$ & $\begin{array}{c}\text { Mean LOS } \\
\text { after } \\
\text { tracheostomy }\end{array}$ & $\begin{array}{c}\text { Mean } \\
\text { AORTIC risk } \\
\text { of death }\end{array}$ & $\begin{array}{c}\text { Mean } \\
\text { APACHE II } \\
\text { score }\end{array}$ \\
\hline Intraabdominal & 36 & 10 & 27.8 & 21 & 57 & 9 & 43 & 0.31 & 22 \\
\hline Respiratory - infective & 29 & 5 & 17.2 & 18 & 62 & 10 & 24 & 0.52 & 25 \\
\hline Exacerbation of COPD & 26 & 5 & 19.2 & 9 & 65 & 9 & 27 & 0.43 & 22 \\
\hline $\begin{array}{l}\text { Respiratory - noninfective, } \\
\text { non-COPD }\end{array}$ & 18 & 3 & 16.7 & 6 & 55 & 10 & 22 & 0.42 & 24 \\
\hline Central nervous system & 16 & 4 & 25 & 8 & 54 & 7 & 17 & 0.45 & 23 \\
\hline Infection - soft tissue & 13 & 5 & 38.5 & 9 & 55 & 13 & 33 & 0.54 & 25 \\
\hline Chest trauma & 10 & 0 & 0 & 8 & 49 & 8 & 22 & 0.20 & 18 \\
\hline Cardiac arrest & 7 & 5 & 71.4 & 5 & 64 & 10 & 10 & 0.62 & 29 \\
\hline Self-harm & 5 & 0 & 0 & 3 & 55 & 7 & 14 & 0.15 & 23 \\
\hline Other & 8 & $\mathrm{I}$ & 12.5 & 3 & 54 & 9 & 44 & 0.43 & 26 \\
\hline Total & 168 & 38 & 22.6 & 90 & 58.9 & 10 & 28.4 & 0.45 & 23 \\
\hline
\end{tabular}

COPD = Chronic obstructive airways disease, ICU = Intensive care unit, LOS = Length of stay, APACHE II = Acute physiology and chronic health evaluation II 
58.9 years, median 60 years). Mortality (in-hospital) in patients aged over 65 years was 38\% (23/61) and 14\% for those aged 22-65 years $(P=0.0004)$. Median day of discharge following tracheostomy was 21.5 (mean 28.4; range $0-164$ ). Hospital length of stay (LOS) ranged from 4 to 171 days (mean 38.7 days, median 32 days); this variable was related to the probability of death on univariate analysis $(P=0.0117)$.

One hundred and forty-seven patients were not extubated prior to tracheostomy $(87.5 \%)$, while $12.5 \%$ patients failed one or more extubation attempts (one failure in 20, two failures in 1). Mortality was $24 \%$ in the never-extubated group and $10 \%$ in those who failed an attempt at extubation $(P=0.1)$. Tracheostomy was performed on inpatient Day 10 (mean 10.6; median 10; range 0-43), which was also Day 10 in ICU (mean 10; median 10; range 0-31). The timing of tracheostomy was not predictive of death $(P=0.6)$. The majority of tracheostomies were surgical (90 surgical and 78 percutaneous). In-hospital mortality was $20 \%$ versus $26 \%$ respectively $(P=0.4)$.

Mortality in patients suffering a cardiac arrest was highest (71\%), followed by soft tissue infection (39\%), intraabdominal disease (28\%; pancreatitis, anastomotic leak, perforated viscus, trauma) and central nervous system disease $(25 \%)$. Mortality in descending order of frequency was seen in exacerbation of chronic obstructive airways disease $(19 \%)$, respiratory infection (17\%), noninfective nonchronic obstructive airways disease (COPD) respiratory disease $(17 \%)$ and miscellaneous conditions $(13 \%)$. No patient with isolated blunt chest trauma or self-harm (poisoning or hanging) died. Seventy-five patients with a respiratory indication for tracheostomy had a mortality of $15 \%$ (aspiration, asthma, exacerbation COPD, pneumonia, pulmonary edema, pneumonitis, isolated blunt chest trauma). Ninety-three patients with a nonrespiratory primary diagnosis had a mortality of $29 \%$ (respiratory vs. nonrespiratory, $P=$ $0.02)$.
Sepsis was diagnosed in 55 (mortality 38.2\%) and absent in 113 (mortality $14.5 \%$; $P=0.0008$ ). Sixty patients $(35.7 \%)$ were not treated for an infection (mortality $14 \%$ ) while 108 patients were treated for an infection at any site (mortality 24\%; $P=0.9$ ). However, 21 of the 55 patients with infection and sepsis died $(38 \%)$, while only three of 53 patients with infection but no sepsis died (6\%), and this difference is highly statistically significant $(P=$ $0.0003)$. Nine of $14(64 \%)$ patients over the age of 65 years with an APACHE II score greater than 22 and a diagnosis of sepsis or cardiac arrest died (just under half did so within 6 days of tracheostomy). The 38 obese patients had a mortality of $18 \%$, while the $77 \%$ who were nonobese (or had no weight recorded) had a mortality of $24 \%$ $(P=0.5)$. A summary of the results is provided in Table 2 .

From the analysis of the chi-squared contingency table tests for each variable (data not shown), a logistic regression was performed. The logistic regression was statistically significant and explains approximately $24 \%$ of the variation in the survival outcome. All of the variables except age, APACHE II score and the AORTIC risk of death variables are statistically significant at a $5 \%$ level of error. Age on admission just marginally exceeds the $5 \%$ level of error $(P=0.05)$. A partial regression of the relationship between APACHE II score and AORTIC risk of death revealed them to be strongly collinear $\left(R^{2}\right.$ $=0.6$ and $P<0.0001$ ). The logistic regression was thus reestimated with the AORTIC risk of death variable omitted, producing the results contained in Table 3.

\section{Discussion}

The purpose of our study was to review the role of tracheostomy in a regional ICU with the view to understanding factors affecting patient selection and outcome. We therefore reviewed all tracheostomies performed on ICU patients in our institution over the past 9 years. The overall mortality rate in our patients with tracheostomy compares favorably with our orotracheal ventilated patients $(29.1 \% ; 295 / 1012)$. Mortality rates

\begin{tabular}{|c|c|c|c|c|c|c|}
\hline Primary diagnosis & Number & Deaths & Mortality (\%) & Nr male & Mean age (years) & Mean ICU LOS \\
\hline Intraabdominal & 205 & 43 & 21.0 & 110 & 61 & 10 \\
\hline Respiratory - infective & 102 & 23 & 22.5 & 55 & 52 & II \\
\hline Exacerbation of COPD & 133 & 39 & 23.9 & 65 & 62 & 6 \\
\hline Respiratory - noninfective, non-COPD & 168 & 24 & 14.3 & 89 & 32 & 5 \\
\hline Central nervous system & 162 & 16 & 9.9 & 105 & 38 & 3 \\
\hline Infection - soft tissue & 41 & 23 & 56.1 & 57 & 59 & 9 \\
\hline Chest trauma & 17 & 0 & 0.0 & 10 & 44 & 10 \\
\hline Cardiac arrest & 29 & 29 & 100.0 & 16 & 60 & I \\
\hline Self-harm & 180 & 0 & 0.0 & 86 & 38 & 2 \\
\hline Other & 659 & 132 & 20.0 & 378 & 42 & 3 \\
\hline Total & 1696 & 329 & 19.4 & 971 & 45.4 & 4.8 \\
\hline
\end{tabular}

COPD = Chronic obstructive airways disease, ICU = Intensive care unit, LOS = Length of stay, APACHE II = Acute physiology and chronic health evaluation II 


\begin{tabular}{|c|c|c|c|c|c|c|c|}
\hline $\begin{array}{l}\text { Logistic regression point } \\
\text { estimates }\end{array}$ & Intercept & Age on admission & Sepsis & Infection & LOS & $\begin{array}{l}\text { APACHE II } \\
\text { score }\end{array}$ & $\begin{array}{l}\text { Cardiac } \\
\text { arrest }\end{array}$ \\
\hline Estimate & -3.729 & 0.033 & 1.276 & -1.582 & -0.024 & 0.041 & 2.315 \\
\hline Standard error & 1.222 & 0.016 & 0.508 & 0.727 & 0.011 & 0.026 & $0.94 I$ \\
\hline $\operatorname{Pr}>\chi^{2}$ & 0.002 & 0.040 & 0.012 & 0.030 & 0.031 & 0.111 & 0.014 \\
\hline R-square ${ }^{[43]}$ & 0.2321 & & & & & & \\
\hline Max-rescaled R-square ${ }^{[43]}$ & 0.3528 & & & & & & \\
\hline Model significance test & $\chi^{2}$ test statistic & Degrees of freedom & $\operatorname{Pr}>\chi^{2}$ & & & & \\
\hline Likelihood ratio & 44.104 & 6 & $<0.0001$ & & & & \\
\hline Score & 39.859 & 6 & $<0.0001$ & & & & \\
\hline Wald & 28.973 & 6 & $<0.0001$ & & & & \\
\hline
\end{tabular}

LOS = Length of stay, APACHE II = Acute physiology and chronic health evaluation II, AORTIC = Australasian outcomes research tool for intensive care,

\begin{tabular}{|c|c|c|c|c|c|c|c|c|}
\hline $\begin{array}{l}\text { Study first author } \\
\text { and year }\end{array}$ & $\begin{array}{c}\text { Total } \\
\text { number of } \\
\text { patients }\end{array}$ & $\begin{array}{l}\text { Number of } \\
\text { patients with } \\
\text { tracheostomy }\end{array}$ & $\begin{array}{c}\text { Mortality for } \\
\text { all patients } \\
\%\end{array}$ & $\begin{array}{c}\text { Mortality for } \\
\text { patients with } \\
\text { tracheostomy \% }\end{array}$ & $\begin{array}{l}\text { Length of } \\
\text { ICU stay } \\
\text { for all } \\
\text { patients } \\
\text { (days) }\end{array}$ & $\begin{array}{l}\text { Length of } \\
\text { ICU stay for } \\
\text { patients with } \\
\text { tracheostomy } \\
\text { (days) }\end{array}$ & $\begin{array}{l}\text { APACHE II } \\
\text { score }\end{array}$ & $\begin{array}{l}\text { SAPS } \\
\text { score }\end{array}$ \\
\hline Present study & 1894 & 168 & $15.5^{*}$ & $22.6^{*}$ & 3.9 & $38.6 \pm 28$ & $\begin{array}{c}8.9(\text { all) } \\
24 \pm 9 \\
\text { (tracheostomy) }\end{array}$ & - \\
\hline Kollef, 1999[25] & 521 & 51 & $25 . I^{*}$ & $13.7^{*}$ & $2.8 \pm 10.1$ & $30.9 \pm 18.1$ & $\begin{array}{c}17.8 \pm 7.2 \text { (all) } \\
19.2 \pm 6.1 \\
\text { (tracheostomy) }\end{array}$ & - \\
\hline Arabi, $2004^{[2]}$ & - & $\begin{array}{l}29 \text { (early) } \\
107 \text { (late) }\end{array}$ & - & $\begin{array}{l}17 \text { (early) } \\
14 \text { (late) }\end{array}$ & - & - & $\begin{array}{l}20 \pm I \text { (early) } \\
19 \pm \text { I (late) }\end{array}$ & - \\
\hline Blot, $2007^{[23]}$ & 123 & 61 & 17.5 & 27 & - & - & - & 50 (both groups) \\
\hline Combes, $2007^{[24]}$ & 506 & 166 & 45 & 37 & $15 \pm 14$ & $4 \mid \pm 27$ & - & $\begin{array}{c}53 \pm 17(\text { all) } \\
53 \pm 16 \\
\text { (tracheostomy) }\end{array}$ \\
\hline Scales, $2008^{[29]}$ & 25,902 & $\begin{array}{l}3758 \text { (early) } \\
7169 \text { (late) }\end{array}$ & - & $\begin{array}{l}35 \text { (early) } \\
\text { (90 days) }\end{array}$ & - & - & - & - \\
\hline Kornblith, $201 \mathrm{I}^{[26]}$ & - & 1000 & - & 12 & - & $29 \pm 0.6$ & - & - \\
\hline Trouillet, 20I | ${ }^{[30]}$ & 3484 & $\begin{array}{l}109 \text { (early) } \\
107 \text { (late) }\end{array}$ & - & $\begin{array}{l}17 \pm 16 \text { (early) } \\
23 \pm 21 \text { (late) }\end{array}$ & - & $\begin{array}{l}24 \pm 21 \text { (early) } \\
26 \pm 22 \text { (late) }\end{array}$ & - & $\begin{array}{l}47 \pm 12 \text { (early) } \\
46 \pm 11 \text { (late) }\end{array}$ \\
\hline $\begin{array}{l}\text { Delaney, 2006[16] } \\
\text { (metaanalysis) }\end{array}$ & 1212 & $\begin{array}{l}45 \mathrm{I} \text { (PDT) } \\
463(\mathrm{ST})\end{array}$ & 37 & $\begin{array}{c}35 \text { (PDT) } \\
39(\mathrm{ST})\end{array}$ & - & - & - & - \\
\hline
\end{tabular}

from other published tracheostomy series can be seen in Table 4. ${ }^{[2,16,18,23-30]}$

The timing of elective tracheostomy in ICU patients remains controversial and is based on the opinions of attending medical staff and policies of individual units. We found the timing of tracheostomy not predictive of death. Our median time to tracheostomy was 10 days post admission to ICU (with a wide range of 0-31 days). Prior studies have produced conflicting results and are complicated by the lack of consensus of what denotes early or late. ${ }^{[2,18,23,27,31,32]}$ Griffiths et al. identified five randomized controlled studies (406 patients) with adequate study design in a recent metaanalysis. ${ }^{[18]}$ No differences in mortality or morbidity were identified, but early tracheostomy was associated with shorter ventilation and ICU LOS. Interpretation of this data is hindered by the small number of patients in each trial, heterogeneity of the populations and variability in study design, with "early" ranging from 0 to 7 days. The Tracman trial will hopefully clarify whether early tracheostomy provides a survival advantage. ${ }^{[33]}$ The investigators intend to randomize patients into an early (1-4 days) and late (>10 days) group. The primary outcome is 30-day mortality. Although completed, data from this study has not been published. Until then, an individual approach to patients is likely to continue.

As might be expected, we found older (age $>65$ years) and sicker patients (APACHE II > 23) to have a higher mortality than younger, less-sick patients. Although our numbers were relatively small, patients with failed extubations faired as well as those without prior extubation attempts, contrary to the seminal paper by Seymour et al. demonstrating an increased risk of death in patients who failed extubation. ${ }^{[34]}$ Overall, patients with nonrespiratory-related disorders faired worse than those with a primary respiratory cause for 
prolonged ventilation. If the primary diagnosis was sepsis, the mortality was more than double that of nonseptic patients. Many patients admitted to our ICU are severely obese and present in cor-pulmonalae. There is a general belief that these patients fare worse than the nonobese patients who undergo tracheostomy, as has been reported in several studies. ${ }^{[35-38]}$ However, a recent metaanalysis failed to find an increased mortality. ${ }^{[39]}$ Our data confirms that there is no increase in mortality in obese patients who require tracheostomy.

While the proportion of tracheostomies being performed percutaneously by intensivists has slowly increased in our ICU over a 9-year period ( $43 \%$ of the first 84 patients and $50 \%$ of the subsequent 84 patients), a significant proportion are still performed by surgeons. We failed to find a difference in mortality between ST and PDT. There are numerous studies and several metaanalyses supporting this finding. ${ }^{[16,40-42]}$ However, two of the latest metaanalyses noted minor discrepancies: Delaney et al. (an intensivist) found no difference in mortality but suggested a decreased incidence of wound infection in patients undergoing PDT. ${ }^{[16]}$ On the other hand, Oliver et al. (a surgeon) found an increase in minor complications in the PDT group compared with bedside ST, and suggested that more care is required in identifying patients for PDT. ${ }^{[28]}$ Notwithstanding the bias introduced by the different author's speciality, there is little to support one technique over the other. Certainly, PDT is quicker and more convenient than ST performed in the operating theater, but bedside ST remains a reasonable alternative. PDT may be limited by a variety of factors, including patient anatomy and coagulopathy, leading, in some instances, to the more difficult cases being performed by surgeons. Ultimately, the decision of which technique to use will depend on patient factors and the skill mix in the hospital.

This study is confined by the limitations of all retrospective, observational studies, namely, difficulty in removing confounders and recall errors. A confounder, in a strict sense, can never be excluded without a systematic double-blinded randomised study. Recall errors were, in the majority, contributed by documentation, including a lack of documentation of the reason for performing tracheostomy. In many instances, the decision to perform a tracheostomy is arbitrary, based on intensivists expectations of LOS and likelihood of weaning to extubation.

Further limitations of the present study include the following. The study was performed in a general medical/ surgical ICU and may not represent more specialized population groups such as trauma, neurosurgical or cardiothoracic. Secondly, deaths resulting from withdrawal of therapy were not documented and may adversely affect mortality results. Thirdly, a long-term follow-up of complications was not undertaken and therefore cannot be included in the analysis.

\section{Conclusion}

In our population cohort, we found that patients with the principle diagnosis of sepsis or who experienced cardiac arrest prior to admission had a significantly worse outcome. Older and sicker patients also had a higher mortality rate. However, approach and timing of tracheostomy, body habitus and source of admission did not affect outcome. Our experience has led us to favor PDT over ST for many reasons, including low complication rates, convenience and the ability to perform the procedure in ICU. Patients who are poor candidates for PDT, usually determined by perceived anatomical difficultly (e.g., short neck, with increased adipose tissue) are taken to the operating theater for an ST. Ultimately, an individualised risk and benefit approach in planning for a tracheostomy may be more appropriate than a routine arbitrarily chosen length of ICU stay.

\section{References}

1. Esteban A, Anzueto A, Frutos F, Alia I, Brochard L, Stewart TE, et al. Characteristics and outcomes in adult patients receiving mechanical ventilation: A 28-day international study. JAMA 2002;287:345-55.

2. Rabi Y, Haddad S, Shirawi N, Al Shimemeri A. Early tracheostomy in intensive care trauma patients improves resource utilization: A cohort study and literature review. Crit Care 2004;8:R347-52.

3. Runicardi FC, Anderson A, Billiar T, Dunn D, Hunter J, Pollock RE. Schwartz's Manual of Surgery. Sydney: McGraw-Hill Professional; 2006

4. Iehl JL, El Atrous S, Touchard D, Lemaire F, Brochard L. Changes in the work of breathing induced by tracheotomy in ventilator-dependent patients. Am J Respir Crit Care Med 1999;159:383-8.

5. Hsu CL, Chen KY, Chang CH, Jerng JS, Yu CJ, Yang PC. Timing of tracheostomy as a determinant of weaning success in critically ill patients: A retrospective study. Crit Care 2005;9:R46-52.

6. Moller MG, Slaikeu JD, Bonelli P, Davis AT, Hoogeboom JE, Bonnell BW. Early tracheostomy versus late tracheostomy in the surgical intensive care unit. Am J Surg 2005;189:293-6.

7. Nieszkowska A, Combes A, Luyt CE, Ksibi H, Trouillet JL, Gibert C, et al. Impact of tracheotomy on sedative administration, sedation level, and comfort of mechanically ventilated intensive care unit patients. Crit Care Med 2005;33:2527-33.

8. Rumbak MJ, Newton M, Truncale T, Schwartz SW, Adams JW, Hazard PB. A prospective, randomized, study comparing early percutaneous dilational tracheotomy to prolonged translaryngeal intubation (delayed tracheotomy) in critically ill medical patients. Crit Care Med 2004;32:1689-94.

9. Koitschev A, Graumueller S, Zenner HP, Dommerich S, Simon C. Tracheal stenosis and obliteration above the tracheostoma after percutaneous dilational tracheostomy. Crit Care Med 2003;31:1574-6.

10. Norwood S, Vallina VL, Short K, Saigusa M, Fernandez LG, McLarty JW. Incidence of tracheal stenosis and other late complications after 
percutaneous tracheostomy. Ann Surg 2000;232:233-41.

11. Stauffer JL, Olson DE, Petty TL. Complications and consequences of endotracheal intubation and tracheotomy. A prospective study of 150 critically ill adult patients. Am J Med 1981;70:65-76.

12. Trottier SJ, Ritter S, Lakshmanan R, Sakabu SA, Troop BR. Percutaneous tracheostomy tube obstruction: Warning. Chest 2002;122:1377-81.

13. Scalise P, Prunk SR, Healy D, Votto J. The incidence of tracheoarterial fistula in patients with chronic tracheostomy tubes: A retrospective study of 544 patients in a long-term care facility. Chest 2005;128:3906-9.

14. Ferraro F, Capasso A, Troise E, Lanza S, Azan G, Rispoli F, et al. Assessment of ventilation during the performance of elective endoscopicguided percutaneous tracheostomy: Clinical evaluation of a new method. Chest 2004;126:159-64.

15. Kluge S, Baumann HJ, Maier C, Klose H, Meyer A, Nierhaus A, et al. Tracheostomy in the intensive care unit: A nationwide survey. Anesth Analg 2008;107:1639-43.

16. Delaney A, Bagshaw SM, Nalos M. Percutaneous dilatational tracheostomy versus surgical tracheostomy in critically ill patients: A systematic review and meta-analysis. Crit Care 2006;10:R55.

17. Esteban A, Anzueto A, Alia I, Gordo F, Apezteguia C, Palizas F, et al. How is mechanical ventilation employed in the intensive care unit? An international utilization review. Am J Respir Crit Care Med 2000;161:1450-8

18. Griffiths J, Barber VS, Morgan L, Young JD. Systematic review and meta-analysis of studies of the timing of tracheostomy in adult patients undergoing artificial ventilation. BMJ 2005;330:1243.

19. MacIntyre NR, Cook DJ, Ely EW Jr, Epstein SK, Fink JB, Heffner JE, et al. Evidence-based guidelines for weaning and discontinuing ventilatory support: A collective task force facilitated by the American College of Chest Physicians; the American Association for Respiratory Care; and the American College of Critical Care Medicine. Chest 2001;120:375S-95S

20. Plummer AL, Gracey DR. Consensus conference on artificial airways in patients receiving mechanical ventilation. Chest 1989;96:178-80.

21. Silvester W, Goldsmith D, Uchino S, Bellomo R, Knight S, Seevanayagam S, et al. Percutaneous versus surgical tracheostomy: A randomized controlled study with long-term follow-up. Crit Care Med $2006 ; 34: 2145-52$.

22. Liu L, Gropper MA. Tracheostomy protocol compliance: Herding cats? Crit Care Med 2008;36:1959-60.

23. Blot F, Similowski T, Trouillet JL, Chardon P, Korach JM, Costa MA, et al. Early tracheotomy versus prolonged endotracheal intubation in unselected severely ill ICU patients. Intensive Care Med 2008;34:1779-87.

24. Combes A, Luyt CE, Nieszkowska A, Trouillet JL, Gibert C, Chastre J. Is tracheostomy associated with better outcomes for patients requiring long-term mechanical ventilation? Crit Care Med 2007;35:802-7.

25. Kollef MH, Ahrens TS, Shannon W. Clinical predictors and outcomes for patients requiring tracheostomy in the intensive care unit. Crit Care Med 1999;27:1714-20.

26. Kornblith LZ, Burlew CC, Moore EE, Haenel JB, Kashuk JL, Biffl WL, et al. One thousand bedside percutaneous tracheostomies in the surgical intensive care unit: Time to change the gold standard. J Am Coll Surg 2011;212:163-70.
27. Lesnik I, Rappaport W, Fulginiti J, Witzke D. The role of early tracheostomy in blunt, multiple organ trauma. Am Surg 1992;58:346-9.

28. Oliver ER, Gist A, Gillespie MB. Percutaneous versus surgical tracheotomy: An updated meta-analysis. Laryngoscope 2007;117:1570-5.

29. Scales DC, Thiruchelvam D, Kiss A, Redelmeier DA. The effect of tracheostomy timing during critical illness on long-term survival. Crit Care Med 2008:36:2547-57.

30. Trouillet JL, Luyt CE, Guiguet M, Ouattara A, Vaissier E, Makri R, et al. Early percutaneous tracheotomy versus prolonged intubation of mechanically ventilated patients after cardiac surgery: A randomized trial. Ann Intern Med 2011;154:373-83.

31. Rodriguez JL, Steinberg SM, Luchetti FA, Gibbons KJ, Taheri PA, Flint LM. Early tracheostomy for primary airway management in the surgical critical care setting. Surgery 1990;108:655-9.

32. Shirawi N, Arabi Y. Bench-to-bedside review: Early tracheostomy in critically ill trauma patients. Crit Care 2006;10:201.

33. Down J, Williamson W. Early vs late tracheostomy in critical care. Br J Hosp Med (Lond) 2009;70:510-3.

34. Seymour CW, Martinez A, Christie JD, Fuchs BD. The outcome of extubation failure in a community hospital intensive care unit: A cohort study. Crit Care 2004;8:R322-7.

35. Bercault N, Boulain T, Kuteifan K, Wolf M, Runge I, Fleury JC. Obesity-related excess mortality rate in an adult intensive care unit: A risk-adjusted matched cohort study. Crit Care Med 2004;32:998-1003.

36. Darrat I, Yaremchuk K. Early mortality rate of morbidly obese patients after tracheotomy. Laryngoseope 2008;118:2125-8.

37. El Solh AA, Jaafar W. A comparative study of the complications of surgical tracheostomy in morbidly obese critically ill patients. Crit Care 2007;11:R3.

38. El-Solh A, Sikka P, Bozkanat E, Jaafar W, Davies J. Morbid obesity in the medical ICU. Chest 2001;120:1989-97.

39. Akinnusi ME, Pineda LA, El Solh AA. Effect of obesity on intensive care morbidity and mortality: A meta-analysis. Crit Care Med 2008;36:151-8

40. Beltrame F, Zussino M, Martinez B, Dibartolomeo S, Saltarini M, Vetrugno L, et al. Percutaneous versus surgical bedside tracheostomy in the intensive care unit: A cohort study. Minerva Anestesiol 2008; 74:529-35.

41. Freeman BD, Isabella K, Cobb JP, Boyle WA 3rd, Schmieg RE Jr, Kolleff MH, et al. A prospective, randomized study comparing percutaneous with surgical tracheostomy in critically ill patients. Crit Care Med 2001;29:926-30.

42. Freeman BD, Isabella K, Lin N, Buchman TG. A meta-analysis of prospective trials comparing percutaneous and surgical tracheostomy in critically ill patients. Chest 2000;118:1412-8.

43. Nagelkerke N.J. A note on a general definition of the coefficient of determination. Biometrika 1991;78:691-2.

How to cite this article: Ho YM, Wysocki AP, Hogan J, White H. An audit of characteristics and outcomes in adult intensive care patients following tracheostomy. Indian J Crit Care Med 2012;16:100-5.

Source of Support: Nil, Conflict of Interest: None declared. 